\title{
Utilization of Non-Living Microalgae Biomass from Two Different Strains for the Adsorptive Removal of Diclofenac from Water
}

\author{
Ricardo N. Coimbra ${ }^{1}{ }^{\complement}$, Carla Escapa ${ }^{1}{ }^{\circledR}$, Nadyr C. Vázquez ${ }^{1}$, Guillermo Noriega-Hevia $^{2}$ and \\ Marta Otero ${ }^{3, *(1)}$ \\ 1 Department of Applied Chemistry and Physics, IMARENABIO-Institute of Environment, \\ Natural Resources and Biodiversity, Campus de Vegazana s/n, Universidad de León, 24071 León, Spain; \\ ricardo.decoimbra@unileon.es (R.N.C.); carla.escapa@unileon.es (C.E.); \\ nvazqs00@estudiantes.unileon.es (N.C.V.) \\ 2 CALAGUA-Unidad Mixta UV-UPV, IIAMA-Research Institute of Water and Environmental Engineering, \\ Camí de Vera s/n, Universitat Politècnica de València, 46022 València, Spain; \\ guillermonoriegahevia@gmail.com \\ 3 CESAM-Centre for Environmental and Marine Studies, Department of Environment and Planning, \\ Campus Universitário de Santiago, University of Aveiro, 3810-193 Aveiro, Portugal \\ * Correspondence: marta.otero@ua.pt; Tel.: +351-234247094
}

Received: 3 September 2018; Accepted: 6 October 2018; Published: 9 October 2018 updates

\begin{abstract}
In the present work, the adsorptive removal of diclofenac from water by biosorption onto non-living microalgae biomass was assessed. Kinetic and equilibrium experiments were carried out using biomass of two different microalgae strains, namely Synechocystis sp. and Scenedesmus sp. Also, for comparison purposes, a commercial activated carbon was used under identical experimental conditions. The kinetics of the diclofenac adsorption fitted the pseudo-second order equation, and the corresponding kinetic constants indicating that adsorption was faster onto microalgae biomass than onto the activated carbon. Regarding the equilibrium results, which mostly fitted the Langmuir isotherm model, these pointed to significant differences between the adsorbent materials. The Langmuir maximum capacity $\left(Q_{\max }\right)$ of the activated carbon $\left(232 \mathrm{mg} \cdot \mathrm{g}^{-1}\right)$ was higher than that of Scenedesmus sp. $\left(28 \mathrm{mg} \cdot \mathrm{g}^{-1}\right)$ and of Synechocystis sp. $\left(20 \mathrm{mg} \cdot \mathrm{g}^{-1}\right)$. In any case, the $Q_{\max }$ values determined here were within the values published in the recent scientific literature on the utilization of different adsorbents for the removal of diclofenac from water. Still, Synechocystis sp. showed the largest $K_{L}$ fitted values, which points to the affinity of this strain for diclofenac at relative low equilibrium concentrations in solution. Overall, the results obtained point to the possible utilization of microalgae biomass waste in the treatment of water, namely for the adsorption of pharmaceuticals.
\end{abstract}

Keywords: emerging contaminants (ECs); sorption; wastewater treatment; bioremediation; algae

\section{Introduction}

Microalgae are photosynthetic microorganisms capable of using $\mathrm{CO}_{2}$ as a carbon source. Thus, as the accumulation of $\mathrm{CO}_{2}$ in the atmosphere is one of the most serious environmental issues to be faced nowadays, the possibility of using microalgae for its sequestration has received great attention [1]. Still, the implementation of $\mathrm{CO}_{2}$ sequestration by microalgae is mostly limited by techno-economic constrains [2]. An option to increase the cost-effectiveness is the cultivation of microalgae in wastewater, which is a complex mixture that may serve as a source of nutrients and water [3]. This strategy allows for nutrient recycling with savings in microalgae cultivation costs and, simultaneously contributes to enhancing the sustainability of wastewater treatment $[4,5]$. 
Interest in microalgae-based wastewater treatment has increased in recent years since, while growing, these microorganisms are able to uptake pollutants like nutrients [6] and trace metals [7], but also emerging contaminants (ECs) such as pharmaceuticals [8-10]. The latter represent an especially worrying class of contaminants since they were designed to provoke a physiological response and their presence in the aquatic environment may affect non-target individuals. Among the different treatments proposed for the removal of pharmaceuticals from wastewater, microalgae-based systems have been proved to be effective either in close [8] or open [11] systems. Whatever the system configuration, biodegradation, together with bioadsorption and bioaccumulation, have been indicated as the main mechanisms for the removal of pharmaceuticals from wastewater [5].

Comparatively with research on the uptake of pharmaceuticals by growing microalgae in wastewater, the utilization of non-living microalgae biomass for the adsorptive removal of these pollutants is still in its early stages $[12,13]$. That is not the case of the well-known adsorption capacity of microalgae to remove other pollutants such as metals [14,15] or dyes [16]. Still, in the case of pharmaceuticals, a main advantage of the application of adsorption processes for their removal is that transformation products, which may be generated during treatments involving degradation $[17,18]$, are not produced. On the other hand, the utilization of the residual microalgae biomass for the adsorption of pollutants from water following the extraction of lipids, has been pointed to as a feasible zero-waste strategy to improve the sustainability of microalgae cultivation [13].

In this context, the aim of this work was to study the adsorptive removal of diclofenac by non-living microalgae biomass of two different strains, namely Scenedesmus sp. (Chlorophyceae) and Synechocystis sp. (Cyanophyceae). For comparison purposes, a commercial activated carbon was used as a reference under the same experimental conditions as microalgae biomass. Diclofenac was selected as target pharmaceutical since it is a nonsteroidal anti-inflammatory drug (NSAID), it is widely consumed, it is one of the pharmaceuticals most frequently present in effluents from sewage treatment plants [19], and it is potentially toxic towards several organisms such as fish and mussels [20]. Moreover, concern about the presence of diclofenac in the aquatic environment has led to its inclusion in the first watch list (EU Decision 2015/495) to support future revisions of the list of priority substances within the Water Framework Directive (2000/60/EC) (WFD) [21].

\section{Materials and Methods}

\subsection{Microalgae and Culture Conditions}

Microalgae from two different genera were used in this work: (i) Scenedesmus sp. (SAG 276-1), which was purchased from the Sammlung von Algenkulturen der Universität Göttingen (Culture Collection of Algae at Göttingen University, international acronym SAG); and (ii) Synechocystis sp., which was isolated from natural freshwater in the surroundings of the province of León [22]. It is to note that the term microalgae was here used in a wide sense, since Cyanophyceae (commonly known as blue green algae) have prokaryotic cell structure like bacteria and, because of that, have also been named as cyanobacteria. An inoculum of each strain was maintained in Erlenmeyer flasks $(250 \mathrm{~mL})$ containing the standard medium Mann and Myers [23] and kept inside a vegetal culture chamber under controlled growth conditions: temperature $\left(25 \pm 1{ }^{\circ} \mathrm{C}\right)$, irradiance $\left(175 \mu \mathrm{mol} \mathrm{photons} \mathrm{m}^{-2} \cdot \mathrm{s}^{-1}\right)$, photoperiod (12:12) and shaking (250 rpm). Then, the cultures were grown in bubbling column photobioreactors (PBRs) with an operation volume of $9 \mathrm{~L}$. PBRs were kept in vegetal culture chambers under controlled conditions, namely at $27-30{ }^{\circ} \mathrm{C}, 16: 8$ photoperiod of light:darkness, and irradiance of $650 \mu \mathrm{E} \cdot \mathrm{m}^{-2} \cdot \mathrm{s}^{-1}$. The microalgae cultures were aerated with filtered air $(0.22 \mu \mathrm{m}$ sterile filters, Millex FG50 Millipore (Merck Millipore, Burlington, MA, USA)) at $0.3 \mathrm{v} / \mathrm{v} / \mathrm{min}$. Air was enriched with $\mathrm{CO}_{2}$ at $7 \% \mathrm{v} / \mathrm{v}$, which was injected on demand to keep a constant $\mathrm{pH}(\mathrm{pH}=7.5 \pm 0.5)$, as controlled by a pH sensor. 


\subsection{Adsorbent Materials and Adsorption Experiments}

For the two different strains, the cellular suspension from each of the aforementioned cultures was centrifuged (7800 rpm, $7 \mathrm{~min}$ ) to separate microalgae biomass from the culture medium. Then, the biomass was washed twice with distilled water, frozen and lyophilized. Before its use as a biosorbent, the lyophilized biomass was grinded and homogenized. For comparison purposes, a commercial activated carbon (PULSORB WP260 (Chemviron Carbon, Feluy, Belgium)), which was generously provided by Chemviron Carbon, was used in this work.

Diclofenac sodium $\left(\mathrm{C}_{14} \mathrm{H}_{10} \mathrm{Cl}_{2} \mathrm{NNaO}_{2}, \geq 99 \%\right.$ ) (Sigma-Aldrich, Madrid, Spain) was used in the adsorption experiments. The concentration of diclofenac in liquid phase was analyzed by a Waters HPLC 600 equipped with a 2487 Dual $\lambda$ Absorbance Detector (Waters Corporation, Milford, MA, USA), a Phenomenex C18 column (Phenomenex España S.L.U., Madrid, Spain), $(5 \mu \mathrm{m}, 110 \AA$, $250 \times 4.6 \mathrm{~mm})$, a Rheodyne injector (Waters Corporation, Milford, MA, USA), and a $50 \mu \mathrm{L}$ loop (Waters Corporation, Milford, MA, USA). The detection wavelength was $276.5 \mathrm{~nm}$ and the mobile phase consisted of acetonitrile:water:orthophosphoric acid (70:30:0.1, v/v/v), which was pumped at $1 \mathrm{~mL} \cdot \mathrm{min}^{-1}$. For the mobile phase preparation, HPLC quality acetonitrile $\left(\mathrm{CH}_{3} \mathrm{CN}\right)$ from LAB-SCAN, orthophosphoric acid $\left(\mathrm{H}_{3} \mathrm{PO}_{4}\right)$ from Panreac and ultrapure water obtained by a Millipore System were used. Before use, the mobile phase mixture was passed through a Millipore filter $(0.45 \mu \mathrm{m})$ and degassed by ultrasound application during $30 \mathrm{~min}$. On the other hand, all the samples were centrifuged at $7500 \mathrm{rpm}$ for 10 min (SIGMA 2-16P centrifuge (Sigma Laborzentrifugen GmbH, Osterode am Harz, Germany), before analysis.

The adsorption experiments were carried out under stirring and batch operation following a parallel approach (a reactor was run by triplicate for each desired time and/or adsorbent mass). Reactors were Erlenmeyer flasks $(100 \mathrm{~mL})$ containing a volume $(V)$ of $50 \mathrm{~mL}$ of solution with a known initial concentration $\left(C_{i}\right)$ of adsorbate, namely diclofenac, together with a known mass $\left(m_{a d s}\right)$ of each adsorbent. Since the adsorption behavior of an adsorbent towards a certain adsorbate is not known a priori, preliminary test were here settled at different $C_{i}$ and $m_{\text {ads }}$ for each material. These tests aimed at the selection of appropriate asorbent to adsorbate ratios for the subsequent kinetic and equilibrium experiments. The choice of the $C_{i}$ and the $m_{\text {ads }}$ for each material, which are specified in the following sections, was such to ensure: (i) a significant change of the adsorbate concentration in solution through adsorption experiments; and (ii) a final concentration of adsorbate that might be accurately and precisely determined by the analytic methodology used.

\subsubsection{Adsorption Kinetics}

For each adsorbent, adsorption kinetic experiments were first carried out in order to determine the time necessary to attain adsorption equilibrium $\left(t_{e}\right)$. In each reactor, a diclofenac solution with $C_{i}=100 \mathrm{mg} \cdot \mathrm{L}^{-1}$ was stirred at $250 \mathrm{rpm}$ under controlled temperature $\left(25 \pm 1{ }^{\circ} \mathrm{C}\right)$ together with a known $\mathrm{m}_{\mathrm{ads}}$. In the case of Scenedesmus sp. and Synechocystis sp., $0.05 \mathrm{~g}$ of biomass were employed whereas $0.005 \mathrm{~g}$ of activated carbon were used in kinetic experiments. After stirring during the desired time $(t)$, reactors were withdrawn, and a sample of the liquid phase was analyzed for the residual concentration of diclofenac $\left(C_{t}\right)$. Three replicated reactors were run for each considered adsorbent and time. Furthermore, blanks (adsorbent + distilled water, without diclofenac in the aqueous phase) and controls (diclofenac solution with no adsorbent) were also run in triplicate. Throughout experiments, the $\mathrm{pH}$ of the solutions was not fixed at any initial value neither buffered, but stability in the values was observed along the kinetic experiments $(7.0 \pm 0.5)$.

At each $t$, the adsorbed concentration of diclofenac onto each adsorbent $\left(q_{t}\right)$ was determined by a mass balance, as indicated by Equation (1):

$$
q_{t}=\frac{\left(C_{i}-C_{t}\right)}{m_{a d s}} \times V
$$


Fittings of the obtained results to the pseudo-first order [24] and the pseudo-second order [25] equations were determined. Both the pseudo-first order (Equation (2)) and the pseudo-second order (Equation (3)) kinetic models are empirical rate equations based on the overall sorption rate:

$$
\begin{gathered}
q_{t}=q_{\mathrm{e}}\left(1-e^{-k_{1} t}\right) \\
q_{t}=\frac{q_{e}^{2} k_{2} t}{1+q_{e} k_{2} t}
\end{gathered}
$$

where $k_{1}\left(\mathrm{~min}^{-1}\right)$ and $k_{2}\left(\mathrm{~g} \mathrm{mg}^{-1} \mathrm{~min}^{-1}\right)$ are the pseudo-first and the pseudo-second order rate constants, respectively, and $q_{e}$ is the adsorbed concentration of diclofenac at the equilibrium.

\subsubsection{Adsorption Equilibrium}

After establishing the $t_{e}$ from kinetic results, adsorption equilibrium experiments were conducted in order to determine the adsorption isotherms. For this purpose, experiments with different $m_{\text {ads }}$ were carried out, each reactor containing $50 \mathrm{~mL}$ of a diclofenac solution with $C_{i}=100 \mathrm{mg} \cdot \mathrm{L}^{-1}$. Reactors were stirred at $250 \mathrm{rpm}$ during the $t_{e}$ and under controlled temperature $\left(25 \pm 1^{\circ} \mathrm{C}\right)$. Equilibrium experiments were run with $0.05 \mathrm{~g} \leq m_{a d s} \leq 0.5 \mathrm{~g}$ of Scenedesmus sp. biomass, $0.05 \mathrm{~g} \leq m_{a d s} \leq 1.25 \mathrm{~g}$ of Synechocysitis sp. biomass, and $0.005 \mathrm{~g} \leq m_{\text {ads }} \leq 0.05 \mathrm{~g}$ of activated carbon. All the experiments were carried out in triplicate, including the corresponding blanks and controls. In each case, the amount of diclofenac adsorbed at the equilibrium $\left(q_{e}\right)$ was determined as a function of the equilibrium concentration $\left(C_{e}\right)$, according to the following mass balance in equation Equation (4):

$$
q_{e}=\frac{\left(C_{i}-C_{e}\right)}{m_{a d s}} \times V
$$

In order to describe the equilibrium isotherms, the fittings of experimental results to the Freundlich [26] and the Langmuir [27] isotherm models, which are respectively expressed by Equations (5) and (6), were determined:

$$
q_{e}=\frac{Q_{\max } K_{L} C_{e}}{1+K_{L} C_{e}}
$$

where $Q_{\max }$ is the maximum adsorption capacity of the adsorbent material and $K_{L}$ is the Langmuir constant, related to the adsorption energy.

$$
q_{e}=K_{f} C_{e}^{\frac{1}{N}}
$$

where $K_{f}$ is the Freundlich constant and $N$ is a constant related to the intensity of the adsorption process.

\section{Results and Discussion}

Controls carried out together with adsorption experiments allowed verifying that diclofenac concentration remained stable throughout the whole duration of the experiments. On the other hand, under the chromatographic operation conditions here used, results from blanks confirmed the absence of analytical interferences by the microalgae biomass or the activated carbon. Therefore, the decrease in diclofenac concentration observed in experiments was expected to be related just to adsorption onto the corresponding material.

The amount of diclofenac adsorbed with time onto biomass of the two microalgae strains considered is shown in Figure 1 together with results obtained for the commercial activated carbon. As can be seen, the adsorbed concentration of diclofenac onto the three adsorbent materials increased with time $(t)$ until reaching the equilibrium. For the tree materials, the equilibrium was attained within $240 \mathrm{~min}$, which was established as $t_{e}$. 
(a)

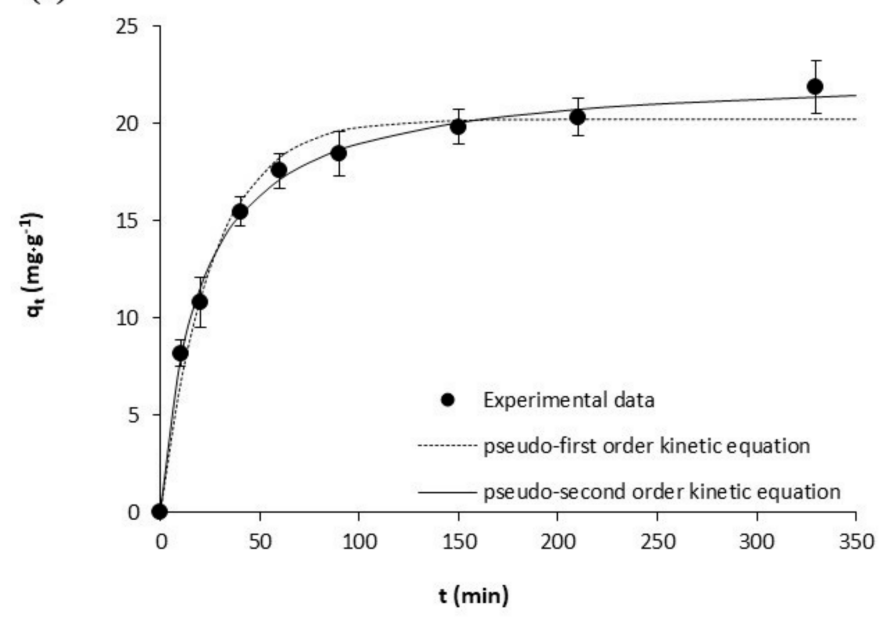

(b)

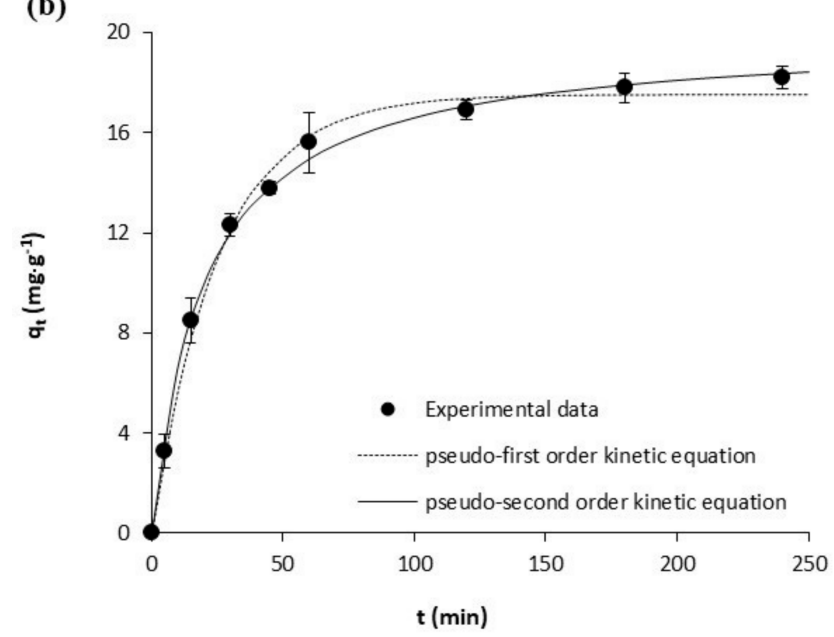

(c)

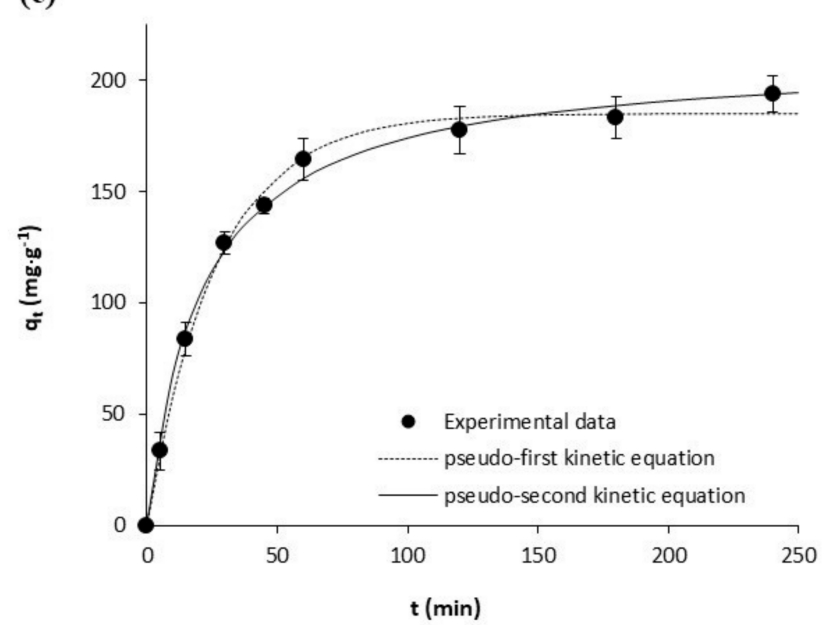

Figure 1. Kinetic results on the adsorption of diclofenac onto (a) Scenedesmus sp. biomass; (b) Synechocystis sp. biomass; and (c) activated carbon. Experimental data on the adsorbed concentration of diclofenac $\left(q_{t}, \mathrm{mg} \cdot \mathrm{g}^{-1}\right)$ versus time $(t, \mathrm{~min})$ are represented together with fittings to the pseudo-first and pseudo-second order kinetic equations. Notes: Error bars stand for standard deviation $(\mathrm{N}=3)$. The scale of the axis has been adjusted for a better visualization of results. 
Fittings of the experimental results to the pseudo-first and pseudo second-order kinetic equations are shown together with the experimental results in Figure 1. The kinetic parameters derived from these fittings are depicted in Table 1. Fittings to both equations were reasonably good, with $r^{2}>0.98$, with the pseudo-second kinetic equation describing results slightly better. Both the kinetic models here considered are based on the adsorbed concentration at the equilibrium $\left(q_{e}\right)$. However, as can be seen in Figure 1, the pseudo-first order model is valid just at the initial stage of adsorption while the pseudo-second model provides good fitting over the whole time range. Hence, in the case of the $k_{1}$, values determined for the three materials were not significantly different, which points to the fact that the initial uptake of diclofenac adsorption by the activated carbon and the microalgae biomasses showed a similar rate. Then, differences in the kinetics occurred at a second stage, which was evidenced by the fitted values of the $k_{2}$ rate constants. These $k_{2}$ were equal for both microalgae strains and larger than that of activated carbon, which indicated that, on the whole, the adsorption kinetic was comparatively faster onto microalgae biomass.

Table 1. Parameters from the experimental results fittings to the kinetic (pseudo-first order kinetic equation and pseudo-second order equation) and equilibrium isotherm (Langmuir and Freundlich equilibrium isotherms) models considered.

\begin{tabular}{|c|c|c|c|c|}
\hline Model & Parameter & Scenedesmus sp. & Synechocystis sp. & Activated Carbon \\
\hline \multicolumn{5}{|c|}{ Kinetic Equations } \\
\hline Pseudo-first order & $\begin{array}{c}k_{1}\left(\mathrm{~min}^{-1}\right) \\
q_{e}\left(\mathrm{mg}^{-\mathrm{g}^{-1}}\right) \\
r^{2} \\
S_{y \cdot x}\end{array}$ & $\begin{array}{c}0.0388 \pm 0.0041 \\
20.19 \pm 0.54 \\
0.981 \\
1.05 \\
\end{array}$ & $\begin{array}{c}0.0393 \pm 0.0024 \\
17.55 \pm 0.30 \\
0.9944 \\
0.52\end{array}$ & $\begin{array}{c}0.0375 \pm 0.0021 \\
184.90 \pm 2.98 \\
0.9951 \\
5.16\end{array}$ \\
\hline Pseudo-second order & $\begin{array}{c}k_{2}\left(\mathrm{~g} \cdot \mathrm{m}^{-1} \cdot \mathrm{min}^{-1}\right) \\
q_{e}\left(\mathrm{mg} \cdot \mathrm{g}^{-1}\right) \\
r^{2} \\
S_{y \cdot x}\end{array}$ & $\begin{array}{c}0.0023 \pm 0.0002 \\
22.64 \pm 0.35 \\
0.9964 \\
0.45 \\
\end{array}$ & $\begin{array}{c}0.0025 \pm 0.0002 \\
19.90 \pm 0.34 \\
0.9968 \\
0.40 \\
\end{array}$ & $\begin{array}{c}0.00022 \pm 0.00002 \\
210.80 \pm 4.50 \\
0.9953 \\
5.09\end{array}$ \\
\hline \multicolumn{5}{|c|}{ Equilibrium Isotherms } \\
\hline Freundlich & $\begin{array}{c}K_{F}\left(\mathrm{mg} \cdot \mathrm{g}^{-1}\left(\mathrm{mg} \cdot \mathrm{L}^{-1}\right)^{-\mathrm{N}}\right) \\
N \\
r^{2} \\
S_{y \cdot x}\end{array}$ & $\begin{array}{c}3.48 \pm 0.17 \\
2.36 \pm 0.07 \\
0.9989 \\
0.26 \\
\end{array}$ & $\begin{array}{c}5.40 \pm 1.01 \\
3.42 \pm 0.61 \\
0.9424 \\
1.78 \\
\end{array}$ & $\begin{array}{c}43.55 \pm 7.48 \\
2.80 \pm 0.36 \\
0.9579 \\
15.23 \\
\end{array}$ \\
\hline Langmuir & $\begin{array}{c}Q_{\max }\left(\mathrm{mg} \cdot \mathrm{g}^{-1}\right) \\
K_{L}\left(\mathrm{~L} \cdot \mathrm{mg}^{-1}\right) \\
r^{2} \\
S_{y \cdot x}\end{array}$ & $\begin{array}{c}28.34 \pm 1.19 \\
0.039 \pm 0.005 \\
0.9941 \\
0.57\end{array}$ & $\begin{array}{c}19.76 \pm 0.57 \\
0.143 \pm 0.018 \\
0.9919 \\
0.66\end{array}$ & $\begin{array}{c}232.20 \pm 7.41 \\
0.076 \pm 0.007 \\
0.9932 \\
6.12\end{array}$ \\
\hline
\end{tabular}

Note: $r^{2}$-Correlation coefficient; $S_{y \cdot x}$-Standard error of the regression.

The diclofenac adsorption equilibrium isotherms using Scenedesmus sp. biomass, Synechocystis sp. biomass and activated carbon as adsorbents are shown in Figure 2.

(a)

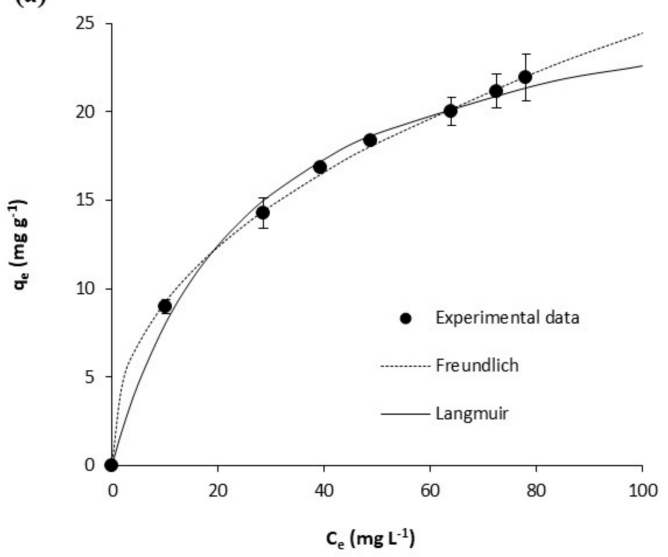

Figure 2. Cont. 
(b)

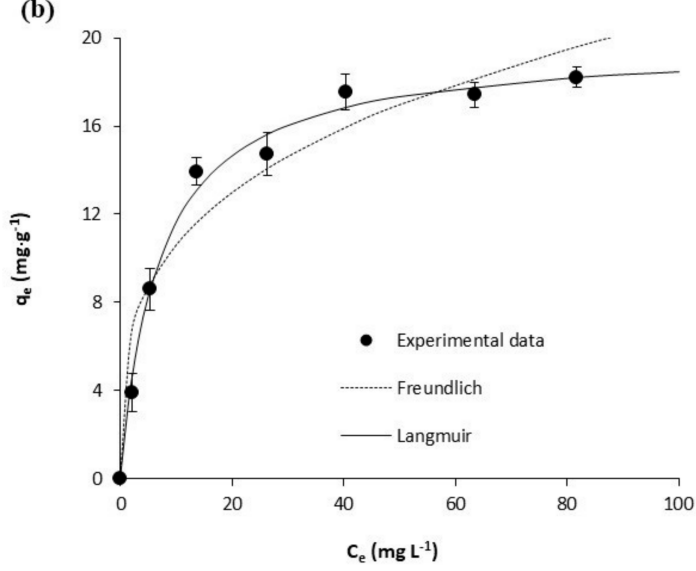

(c)

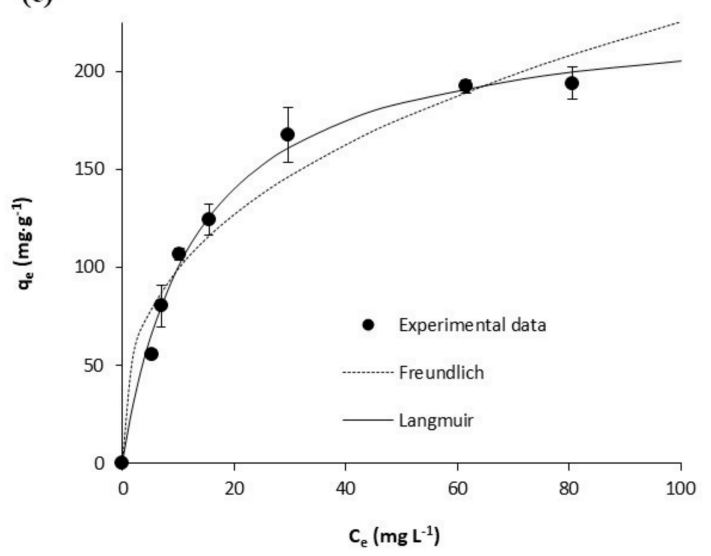

Figure 2. Equilibrium results on the adsorption of diclofenac onto (a) Scenedesmus sp. biomass; (b) Synechocystis sp. biomass; and (c) activated carbon. Experimental data on the equilibrium adsorbed concentration of diclofenac $\left(q_{e}, \mathrm{mg} \cdot \mathrm{g}^{-1}\right)$ versus the equilibrium diclofenac concentration in the liquid phase $\left(C_{e}, \mathrm{mg} \cdot \mathrm{L}^{-1}\right)$ are represented together with fittings to the Langmuir and Freundlich equilibrium isotherm models. Notes: error bars stand for standard deviation $(\mathrm{N}=3)$. The scale of the axis has been adjusted for a better visualization of results.

Fittings of equilibrium experimental results to the Freundlich and Langmuir models are represented in Figure 2, the corresponding fitted parameters being depicted in Table 1.

In the case of diclofenac adsorption onto Scenedesmus sp. biomass, equilibrium results fitted the Freundlich and Langmuir isotherm models, with $r^{2}>0.99$ in both cases. However, for both the Synechocystis sp. biomass and the commercial activated carbon, equilibrium results were better described by the Langmuir isotherm.

Figure 2 makes evident that, at the equilibrium, the adsorptive removal of diclofenac by the activated carbon used here was larger than that of microalgae biomasses. On the other hand, the diclofenac adsorption capacity of Scenecesmus sp. was significantly larger than that of Synechocystis sp., which may be confirmed by $Q_{\max }$ values in Table 1 . According to the Langmuir isotherm model [27], the $Q_{\max }$, which is the maximum adsorption capacity, corresponds to the saturation of a monolayer of adsorbate molecules on the adsorbent surface, that is, when all the adsorption sites of the adsorbent are occupied by adsorbate molecules. Therefore, each adsorbent possesses a unique $Q_{\max }$ for each adsorbate and, in wastewater treatment applications, a larger value of $Q_{\max }$ implies that the adsorbent material will have a longer useful lifetime. Hence, $Q_{\max }$ is used for the prediction of the adsorbent performance in real systems and for the design of adsorbers at different scales [28]. In this work, the $Q_{\max }$ determined for activated carbon $\left(232 \mathrm{mg} \cdot \mathrm{g}^{-1}\right)$ was larger than that of Scenedesmus sp. and 
Synechocystis sp. (28 mg.g ${ }^{-1}$ and $20 \mathrm{mg} \cdot \mathrm{g}^{-1}$, respectively). In any case, the here obtained $Q_{\max }$ values for the adsorption of diclofenac onto microalgae biomass are higher than those determined for the adsorption of different polyphenols $\left(8 \mathrm{mg} \cdot \mathrm{g}^{-1}<Q_{\max }<19 \mathrm{mg} \cdot \mathrm{g}^{-1}\right)$ onto non-living Chlorella sp. biomass [29] but lower than for the adsorption of acetaminophen onto Synechocystis sp. $\left(52 \mathrm{mg} \cdot \mathrm{g}^{-1}\right)$. With respect to other materials used for the adsorptive removal of diclofenac from water, Table 2 shows recently $Q_{\max }$ published values for adsorbents of different nature. As may be seen, the range is quite large and comprises the here obtained $Q_{\max }$.

Regarding the $K_{L}$, which points to the affinity of an adsorbent towards the adsorbate, the fitted value determined for Synechocystis sp. $\left(0.14 \mathrm{~L} \cdot \mathrm{mg}^{-1}\right)$ is within values obtained for the adsorption of polyphenols onto Chlorella sp. $\left(0.09-0.022 \mathrm{~L} \cdot \mathrm{mg}^{-1}\right)$ [29]. For the commercial activated carbon and Scenedesmus sp., the $K_{L}$ determined was one order of magnitude lower than that of Synechocystis sp., as for the steeper isotherm of the latter (Figure 2). Therefore, although Synechocystis sp. displayed the smallest value of maximum adsorption capacity, this $Q_{\max }$ was attained at relatively low $C_{e}$ of diclofenac in solution.

Table 2. Maximum adsorption capacities $Q_{\max }\left(\mathrm{mg} \cdot \mathrm{g}^{-1}\right)$ of different types of adsorbents used for the adsorptive removal of diclofenac from water (single non-competitive adsorption; $\mathrm{T}: 25 \pm 2{ }^{\circ} \mathrm{C} ; \mathrm{pH}: 7 \pm 2$ ).

\begin{tabular}{ccc}
\hline Adsorbent & $Q_{\max } \mathbf{( m g \cdot \mathbf { g } ^ { - \mathbf { 1 } } )}$ & Reference \\
\hline Activated onion skin & 134 & {$[30]$} \\
Metal azolate framework-6 & 503 & {$[31]$} \\
Activated cork & 79 & {$[31]$} \\
Pyrolyzed pulp mill sludge & 27 & {$[32]$} \\
Granular activated carbon & 36 & {$[33]$} \\
Activated carbon from olive stones & 11 & {$[34]$} \\
Ionic liquid modified biomass & 197 & {$[35]$} \\
MIEX ${ }^{\circledR}$ resin & 52 & {$[36]$} \\
Molecular imprinted polymer & 160 & {$[37]$} \\
Powder activated carbon & 301 & {$[38]$} \\
Polymeric resin & 39 & {$[38]$} \\
\hline
\end{tabular}

To the best of our knowledge, there are not previous records in the literature on the adsorptive different performance of Scenedesmus sp. and Synechocystis sp. biomass observed in this work. It must be highlighted that, in the present work, microalgae biomass used was not previously modified neither subjected to thermal treatment. Thus, differences between the two strains regarding the adsorption of diclofenac may be related to their cell wall and biochemical composition. In fact, it has already being pointed out that the microalgae cell surface possesses a rich variety of binding possibilities for a whole range of chemical compounds [29].

Microalgae constitute a group of microorganisms that are easy to culture due to their high growth rates and productivities and, therefore, microalgae biotechnological applications are under expansion [29]. Among the strategies to reduce costs associated with the culture of microalgae is the utilization of flue gases as $\mathrm{CO}_{2}$ supply and wastewater as nutrients and freshwater source [3]. In this way, microalgae could be used for the biosequestration of $\mathrm{CO}_{2}$ while accomplishing wastewater treatment [39]. In any case, during cultivation, waste microalgae biomass is generated and a use should be given to this biomass within the actual circular economy context. Therefore, the utilization of microalgae biomass as adsorbent may be an option for increasing the sustainability of microalgae culture. Furthermore, such a use is especially interesting since it may be implemented after lipid extraction from non-living microalgae [13]. As diclofenac is among the pharmaceuticals within the first watch list in the European Union (EU) [21], the novel results obtained in this work on its uptake by non-living microalgae biomass point to the possible application of this biomass for the adsorptive removal of this sort of emerging contaminant. Promissory results obtained in the present work show that this is a new line of research that is worth to further exploring. In this sense, future studies are to be done on the application at real systems, in which fixed-bed microalgae adsorbers may be implemented by the immobilization of microalgae biomass. Although there are no published results for the removal 
of pharmaceuticals, Saeed and Iqbal [40] immobilized a blue green microalga, namely Synechococcus sp. on loofa (Luffa cylindrical) sponge for the fixed-bed adsorptive removal of cadmium from water, a strategy that was later adopted by Chen et al. [41], who used Scenedesmus obliquus as biosorbent.

\section{Conclusions}

The microalgae non-living biomass of two different strains, namely Scenedesmus sp. and Synechocystis sp. was used for the adsorptive removal of diclofenac from water. Kinetic and equilibrium results were compared with those obtained by a commercial activated carbon under identical experimental conditions. Fittings of the kinetic experimental results to the pseudo-second kinetic equation showed that the rate of diclofenac uptake from aqueous solution was similar for both microalgae strains and faster than that of activated carbon. Regarding the equilibrium experimental results, the Langmuir isotherm model described the results for the three adsorbents. The fitted values of the Langmuir maximum adsorption capacity $\left(Q_{\max }\right)$ were 232,28 and $20 \mathrm{mg} \cdot \mathrm{g}^{-1}$ of diclofenac onto the activated carbon, Scenedesmus sp. biomass and Synechocystis sp. biomass, respectively. These values are within recently published $Q_{\max }$ for the adsorptive removal of diclofenac from water using different adsorbents. Differently from these adsorbents in the literature, microalgae biomass here used was neither modified nor treated, its use as biosorbent being an option to explore in view of a sustainable zero-waste strategy for the culture of microalgae.

Author Contributions: R.N.C., C.E. and M.O. conceived the work and the experimental design; R.N.C., C.E., N.C.V., G.N.-H. and M.O. performed the experiments and chemical analysis; R.N.C., C.E. and M.O. analysed the results and wrote the manuscript. All the authors approved the submitted final version.

Funding: This research was funded by Fundação para a Ciência e a Tecnologia (FCT, Lisboa, Portugal), grant number IF/00314/2015; by the Ministry of Economy and Competitiveness, State Secretariat for Research, Development and Innovation (Madrid, Spain), grant number RYC 2010-05634; and by University of León (Spain), grant number UXXI2016/00128. C.E. was funded by the Ministry of Education, Culture and Sports (Madrid, Spain), grant number FPU12/03073.

Acknowledgments: Thanks are due for financial support to CESAM (UID/AMB/50017-POCI-01-0145FEDER-007638), to FCT/MCTES through national funds (PIDDAC), and co-funding by FEDER, within the PT2020 Partnership Agreement and Compete 2020.

Conflicts of Interest: The authors declare the inexistence of conflict of interest. They also declare that the founding agents did not participate in nor decide on the design of the study, the chemical analysis, the interpretation of results, and the writing and publishing of the manuscript.

\section{References}

1. Cheah, W.Y.; Show, P.L.; Chang, J.S.; Ling, T.C.; Juan, J.C. Biosequestration of atmospheric $\mathrm{CO}_{2}$ and flue gas-containing $\mathrm{CO}_{2}$ by microalgae. Bioresour. Technol. 2015, 184, 190-201. [CrossRef] [PubMed]

2. Kassim, M.A.; Meng, T.K. Carbon dioxide $\left(\mathrm{CO}_{2}\right)$ biofixation by microalgae and its potential for biorefinery and biofuel production. Sci. Total Environ. 2017, 584-585, 1121-1129. [CrossRef] [PubMed]

3. Acién, F.G.; Fernández, J.M.; Magan, J.J.; Molina, E. Production cost of a real microalgae production plant and strategies to reduce it. Biotechnol. Adv. 2012, 30, 1344-1353. [CrossRef] [PubMed]

4. Kim, J.-Y.; Kim, H.-W. Photoautotrophic microalgae screening for tertiary treatment of livestock wastewater and bioresource recovery. Water 2017, 9, 192. [CrossRef]

5. Xiong, J.-Q.; Kurade, M.B.; Jeon, B.-H. Can microalgae remove pharmaceutical contaminants from water? Trends Biotechnol. 2018, 36, 30-44. [CrossRef] [PubMed]

6. Khiewwijit, R.; Rijnaarts, H.; Temmink, H.; Keesman, K.J. Glocal assessment of integrated wastewater treatment and recovery concepts using partial nitritation/Anammox and microalgae for environmental impacts. Sci. Total Environ. 2018, 628, 74-84. [CrossRef] [PubMed]

7. Rugnini, L.; Costa, G.; Congestri, R.; Bruno, L. Testing of two different strains of green microalgae for $\mathrm{Cu}$ and Ni removal from aqueous media. Sci. Total Environ. 2017, 601-602, 959-967. [CrossRef] [PubMed]

8. Hom-Diaz, A.; Jaén-Gil, A.; Bello-Laserna, I.; Rodríguez-Mozaz, F.; Vicent, T.; Barceló, D.; Blánquez, P. Performance of a microalgal photobioreactor treating toilet wastewater: Pharmaceutically active compound removal and biomass harvesting. Sci. Total Environ. 2017, 592, 1-11. [CrossRef] [PubMed] 
9. Escapa, C.; Coimbra, R.N.; Paniagua, S.; García, A.I.; Otero, M. Comparative assessment of pharmaceutical removal from wastewater by the microalgae Chlorella sorokiniana, Chlorella vulgaris and Scenedesmus obliquus. In Biological Wastewater Treatment and Resource Recovery; IntechOpen: London, UK, 2017.

10. Escapa, C.; Coimbra, R.N.; Paniagua, S.; García, A.I.; Otero, M. Comparative assessment of diclofenac removal from water by different microalgae strains. Algal Res. 2016, 18, 127-134. [CrossRef]

11. de Godos, I.; Muñoz, R.; Guieysse, B. Tetracycline removal during wastewater treatment in high-rate algal ponds. J. Hazard. Mater. 2012, 229, 446-449. [CrossRef] [PubMed]

12. Escapa, C.; Coimbra, R.N.; Nuevo, C.; Vega, S.; Paniagua, S.; García, A.I.; Calvo, L.F.; Otero, M. Valorization of microalgae biomass by its use for the removal of paracetamol from contaminated water. Water 2017, 9, 312. [CrossRef]

13. Angulo, E.; Bula, L.; Mercado, I.; Montaño, A.; Cubillán, N. Bioremediation of Cephalexin with non-living Chlorella sp. biomass after lipid extraction. Bioresour. Technol. 2018, 257, 17-22. [CrossRef] [PubMed]

14. Brinza, L.; Dring, M.J.; Gavrilescu, M. Marine micro and macro algal species as biosorbents for heavy metals. Env. Eng. Manag. J. 2007, 6, 237-251. [CrossRef]

15. Sutkowy, M.; Kłosowski, G. Use of the coenobial green algae Pseudopediastrum boryanum (Chlorophyceae) to remove hexavalent chromium from contaminated aquatic ecosystems and industrial wastewaters. Water 2018, 10, 712. [CrossRef]

16. Tsai, W.-T.; Chen, H.-R. Removal of malachite green from aqueous solution using low-cost chlorella-based biomass. J. Hazard. Mater. 2010, 175, 844-849. [CrossRef] [PubMed]

17. Peng, F.; Ying, G.; Yang, B.; Liu, S.; Lai, H.; Liu, Y.; Chen, Z.; Zhou, G. Biotransformation of progesterone and norgestrel by two freshwater microalgae (Scenedesmus obliquus and Chlorella pyrenoidosa): transformation kinetics and products identification. Chemosphere 2014, 95, 581-588. [CrossRef] [PubMed]

18. Escapa, C.; Torres, T.; Neuparth, T.; Coimbra, R.N.; García, A.I.; Santos, M.M.; Otero, M. Zebrafish embryo bioassays for a comprehensive evaluation of microalgal efficiency in the removal of diclofenac from water. Sci. Total Environ. 2018, 640, 1024-1033. [CrossRef] [PubMed]

19. Pal, A.; Gin, K.Y.H.; Lin, A.Y.-C.; Reinhard, M. Impacts of emerging organic contaminants on freshwater resources: Review of recent occurrences, sources, fate and effects. Sci. Total Environ. 2010, 408, 6062-6069. [CrossRef] [PubMed]

20. Lonappan, L.; Brar, S.K.; Das, R.K.; Verma, M.; Surampalli, R.Y. Diclofenac and its transformation products: Environmental occurrence and toxicity-A review. Environ. Int. 2016, 96, 127-138. [CrossRef] [PubMed]

21. Barbosa, M.O.; Moreira, N.F.F.; Ribeiro, A.R.; Pereira, M.F.R.; Silva, A.M.T. Occurrence and removal of organic micropollutants: An overview of the watch list of EU Decision 2015/495. Water Res. 2016, 94, 257-279. [CrossRef] [PubMed]

22. Martínez, L.; Otero, M.; Morán, A.; García, A.I. Selection of native freshwater microalgae and cyanobacteria for $\mathrm{CO}_{2}$ biofixation. Environ. Technol. 2013, 34, 3137-31435. [CrossRef] [PubMed]

23. Mann, J.; Myers, J. On pigments growth and photosynthesis of Phaeodactylum Tricornutum. J. Phycol. 1968, 4, 349-355. [CrossRef] [PubMed]

24. Lagergren, S. Zur theorie der sogenannten adsorption gelöster stoffe. Kungliga Svenska Vetenskapsakademiens. Handlingar 1808, 24, 1-39.

25. Ho, I.S.; McKay, G. Pseudo-second order model for sorption processes. Process Biochem. 2011, 34, 451-465. [CrossRef]

26. Freundlich, H. Über die Adsorption in Lösungen. Z. Phys. Chem. 1906, 57, 385-470. [CrossRef]

27. Langmuir, I. The Adsorption of Gases on Plane Surfaces of Glass, Mica and Platinum. J. Am. Chem. Soc. 1918, 40, 1361-1403. [CrossRef]

28. Otero, M.; Zabkova, M.; Grande, C.A.; Rodrigues, A.E. Fixed-bed adsorption of salicylic acid onto polymeric adsorbents and activated charcoal. Ind. Eng. Chem. Res. 2005, 44, 927-936. [CrossRef]

29. Jelínek, L.; Procházková, G.; Quintelas, C.; Beldíková, E.; Brányik, T. Chlorella vulgaris biomass enriched by biosorption of polyphenols. Algal Res. 2015, 10,1-7. [CrossRef]

30. Abbas, G.; Javed, I.; Iqbal, M.; Haider, R.; Hussain, F.; Qureshi, N. Adsorption of non-steroidal anti-inflammatory drugs (diclofenac and ibuprofen) from aqueous medium onto activated onion skin. Desalin. Water Treat. 2017, 95, 274-285. [CrossRef] 
31. An, H.J.; Bhadra, B.N.; Khan, N.A.; Jhung, S.H. Adsorptive removal of wide range of pharmaceutical and personal care products from water by using metal azolate framework-6-derived porous carbon. Chem. Eng. J. 2018, 343, 447-454. [CrossRef]

32. Coimbra, R.N.; Calisto, V.; Ferreira, C.I.A.; Esteves, V.I.; Otero, M. Removal of pharmaceuticals from municipal wastewater by adsorption onto pyrolyzed pulp mill sludge. Arab. J. Chem. 2015. [CrossRef]

33. de Franco, M.A.E.; de Carvalho, C.B.; Bonetto, M.M.; de Pelegrini Soares, R.; Féris, L.A. Diclofenac removal from water by adsorption using activated carbon in batch mode and fixed-bed column: Isotherms, thermodynamic study and breakthrough curves modelling. J. Clean. Prod. 2018, 181, 145-154. [CrossRef]

34. Larous, S.; Meniai, A.-H. Adsorption of diclofenac from aqueous solution using activated carbon prepared from olive stones. Int. J. Hydrogen Energy 2016, 41, 10380-10390. [CrossRef]

35. Lawal, I.A.; Moodley, B. Sorption mechanism of pharmaceuticals from aqueous medium on ionic liquid modified biomass. J. Chem. Tech. Biotech. 2017, 92, 808-818. [CrossRef]

36. Lu, X.; Shao, Y.; Gao, N.; Chen, J.; Zhang, Y.; Wang, Q.; Lu, Y. Adsorption and removal of clofibric acid and diclofenac from water with MIEX resin. Chemosphere 2016, 161, 400-411. [CrossRef] [PubMed]

37. Samah, N.A.; Sánchez-Martín, M.-J.; Sebastián, R.M.; Valiente, M.; López-Mesas, M. Molecularly imprinted polymer for the removal of diclofenac from water: Synthesis and characterization. Sci. Total Environ. 2018, 631, 1534-1543. [CrossRef] [PubMed]

38. Coimbra, R.N.; Escapa, C.; Paniagua, S.; Otero, M. Adsorptive removal of diclofenac from ultrapure and wastewater: a comparative assessment on the performance of a polymeric resin and activated carbons. Desalin. Water Treat. 2016, 57, 27914-27923. [CrossRef]

39. Markou, G.; Wang, L.; Ye, J.; Unc, A. Using agro-industrial wastes for the cultivation of microalgae and duckweeds: Contamination risks and biomass safety concerns. Biotechnol. Adv. 2018, 36, 1238-1254. [CrossRef] [PubMed]

40. Chen, B.-Y.; Chen, C.-Y.; Guo, W.-Q.; Chang, H.-W.; Chen, W.-M.; Lee, D.-J.; Huang, C.-C.; Ren, N.-Q.; Chang, J.-S. Fixed-bed biosorption of cadmium using immobilized Scenedesmus obliquus CNW-N cells on loofa (Luffa cylindrica) sponge. Bioresource Technol. 2014, 160, 175-181. [CrossRef] [PubMed]

41. Saeed, A.; Iqbal, M. Immobilization of blue green microalgae on loofa sponge to biosorb cadmium in repeated shake flask batch and continuous flow fixed bed column reactor system. World J. Microbiol. Biotechnol. 2016, 22, 775-782. [CrossRef] 